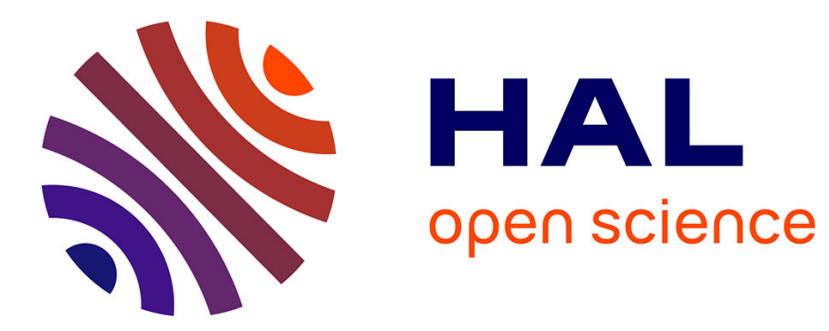

\title{
Images of English in the French Press
}

Marc Deneire

\section{To cite this version:}

Marc Deneire. Images of English in the French Press. Andrew Linn, Neil Bermel, Gibson Ferguson. Attitudes towards English in Europe, De Gruyter, pp.XX, 2014. hal-00944974

\section{HAL Id: hal-00944974 https://hal.science/hal-00944974}

Submitted on 20 Feb 2020

HAL is a multi-disciplinary open access archive for the deposit and dissemination of scientific research documents, whether they are published or not. The documents may come from teaching and research institutions in France or abroad, or from public or private research centers.
L'archive ouverte pluridisciplinaire $\mathbf{H A L}$, est destinée au dépôt et à la diffusion de documents scientifiques de niveau recherche, publiés ou non, émanant des établissements d'enseignement et de recherche français ou étrangers, des laboratoires publics ou privés. 


\section{Images of English in the French Press}

Marc Deneire

Université de Lorraine

This paper attempts to question the image of a one-sided monolithic French resistance to the spread of English. For this purpose, a corpus of over one thousand articles from newspapers and magazines traditionally associated with different political views such as Le Monde and Liberation for the left and Le Figaro for the right, as well as newsletters and other materials published by the corporate world and trade-unions is analysed using Hyperbase for a principal component analysis and Alceste for a descending hierarchical classification that breaks the corpus down in different classes. .

The purpose of the paper is to establish relations between various social strata, institutional environments, ideological positions, and economic interests on the one hand, and the different attitudes towards English, ranging from enthusiastic adoption by the business world to fierce ideological opposition based on centuries-old forms of antiAmericanism and linguistic protectionism. The results show that traditional cultural resistance to English is limited to a small set of national newspapers, regardless of ideological orientation. At the opposite end, business-oriented newspapers and magazines tend to encourage the use of English. Finally, the issue is almost completely absent from the widelyread regional press, which suggests that it is of minor importance for most of the French in their daily lives.

Through this study, I hope to give a more nuanced and diverse picture of French attitudes towards English than that which is usually presented in the English-speaking press and in academia.

\section{Introduction}

French efforts to protect their language against the invasion of English have often met with scathing criticism in the English-speaking world which sees these as many signs of French dirigisme, Jacobinism, and democratic deficit. The first piece of language policy, the Edict of Villers-Cotterêt, which intended to progressively replace Latin with French, is described as a first step in the imposition of French upon a largely multi-lingual population. Another favorite target in conferences and publications is the Académie Française whose "irreproachable uselessness," in the words of French linguist Robitaille (2002: 15) is often misrepresented as a guardian that holds the French language back instead of letting it live its own life as English does. For Carla Power (2007), the members of the Academy "are given swords and charged with defending the sanity of the French language," and Campbell writes in the Sunday Times that while "English borrows liberally from French, (. . . ) the French are less laissez-faire: a hallowed academy of elders known as "immortals" zealously polices the official lexicon against English intruders and 'Globish"' (cited in Estival and Pennycook 2011: 328). Even David Crystal argues that the supposed role of the Academy in "forbidding" 
loanwords has, as it were, constrained the French language in a stand and prevented it from developing. For him, the absence of an academy has allowed English to develop freely: "What would have happened to the English language if it had forbidden the arrival of loanwords? It would be a language a tenth of the size it is today, and it would never have become the language of science. English has, like a vacuum cleaner, sucked in words from 350 languages during the past 1,000 years" (2005: 10). Finally, French language policy has often been ridiculed for its limited success. For example, the 1994 Toubon law, which aimed at protecting monolingual workers and consumers from documents and labels they don't understand, has been criticized for its limited success (Kibbee 1993: 210) and its naïveté when faced with the users linguistic creativity, especially in advertising (Martin 2007: 171).

Even though these mostly American reactions against French language policy are often clearly biased and uninformed, French reactions against English do exist, as recent articles and books by linguists and commentators decrying the use of English words attest. For example, Claude Hagège's Combat pour le Français (2008) and his numerous newspaper articles that are used in my corpus continue a line of conservative essays that started with the late Etiemble's Parlez vous Franglais? Along the same lines, philosopher Michel Serres (who lives in the United-States) asserted that "We see more English words on the walls of Toulouse today than [we saw] German words during the occupation" (2013), attesting to the polemical nature of these arguments. Yet, as many studies and statistics have demonstrated, most French people claim to be open to the learning and use of the English language (see Flaitz 1988, Martin 1998, and Deneire 2008 for field studies and Euridyce 2008 for statistics in education). In the present paper, I will use an extensive corpus of newspapers and magazines to offer a more nuanced picture of French attitudes toward English today and to give a mmore complex picture than the often simplistic and reductionist views discussed above.

\section{Theoretical assumptions}

In choosing media, I follow the footsteps of a large number of discourse analysts who take for granted that newspapers and magazines reflect and reproduce opinions and ideologies (Fairclough 1995: 46, Blommaert 2005: 3). As Van Dijk has argued (1988: 24), media discourse instantiates ideologies as "mental structures" in social situations. Media are economically highly dependent on their readership for survival, as regular efforts by major 
newspapers (Le Monde, Libération) to change their presentation and adapt to their readers' modes of consumption attests (Motte, 2012). Therefore, we may assume a dialectic relationship in which: (1) media texts reflect the collective view of a large number of their readers (Bell 1991); (2) they affect the horizons of their readers through the selection of information, textual structure; and processes of foregrounding and backgrounding; and (3) they frame the world in particular ways. In the words of A. Bell, "Media 'discourse' is important for what it reveals about a society and because it contributes to the character of society" (1998: 64). Finally, we can also assume that the existence of several major newspapers is a reflection of different worldviews that circulate in society, otherwise, they would not survive. For this reason, I included all major French newspapers in my corpus.

Media are organized differently from country to country; however, in most Western nations, a distinction can be made between the general press that contains political information and commentaries and is read by a relatively small educated elite on the one hand, and the popular press that contains almost no such information but rather local events, gossip (in French: les potins) and sports (see older and more recent surveys in Bourdieu, 1979: 519, Dumartin and Maillard, 2000, and PAR66 One, 2011). In France, the former includes most national newspapers (Le Monde, Le Figaro, Libération), and the latter consists of the regional press. Tabloids equivalent to the British Sun or Daily Mirror have disappeared completely in France and been replaced with popular magazines of which the French are avid readers (an average of 7.3 magazines per person every year; Duval 2014). Some magazines also focus on general information (Le Point, L'Express) or on specific information (Capital, (economy) L'informatique, (computer science)). As table 1 shows, 50 percent of the French above the age of 15 read a newspaper everyday: 36 percent of them read a regional newspaper everyday (63 percent at least once a week) while 15,5 percent, that is less than one person out of six, read a national newspaper ever day. Thus, there is a clear divide between the readership of the major newspapers that consists of a relatively small cultured elite, and that of the regional press that mainly includes workers, farmers, and retired people. Finally, an increasing number of people read the free newspapers (Metro, 20 minutes) that become available in most larger cities. However, these are not represented in the corpus for this study. 
Table 1: Newspaper readership in 2011

(PQR66 One, 2011)*

\begin{tabular}{|l|l|l|}
\hline Readership & In 1000 & In \% \\
\hline Total & 25.54 & 50.2 \\
\hline Regional press & 18.55 & 36.5 \\
\hline National press & 7.892 & 15,5 \\
\hline Free press & 7.668 & 11,7 \\
\hline
\end{tabular}

*Based on 35600 interviews, of which at least 300 in each of the 96 départements

\section{Sampling and methodology.}

The corpus for this study was built with a concern for diversity with the criteria outlined above in mind. Articles from magazines were also included because, as mentioned above, the latter represent an important part of what the French read every day. Using the academic databases Nexis Lexis and Europress, I selected that articles that contained the words "anglais", "français", and "langue" in the newspapers listed in table 2 between 2005 and 2011. The articles that were obviously unrelated to the topic (e.g., concerning culinary matters or fashion) were removed. This yielded a corpus of more than 1000 articles, that is, around 831 thousand words.

Table 2: The corpus (with approximate number of articles)

National newspapers - General
Le Monde (60), Le Monde Diplomatique (36), Le Figaro (80), Libération (40),
l'Humanité (57).
Economic/business newspapers

La Tribune (48), Les Echos (136), Informatique (43), L'Expansion (22)
National magazines

Le Point (50), L'Express (42), Marianne (56)
Regional newspapers
Le Télégramme (50), La Nouvelle République du Centre Ouest (57), Ouest-
France(43), Paris-Normandie, l'Est Républicain (85), etc.


I used three complementary tools for analysis: Wordsmith Tools (version 4) for word lists and the extraction of collocates, Hyperbase to establish the lexical distance (that is, the number of words that are present or absent in each part of the corpus and the frequency of these words; Bonin and Dallo 2003: 393) between the different newspapers and magazines and Alceste for factor analysis. Both Alceste and Hyperbase perform correspondence factor analysis, a multivariate clustering technique that detects associations and oppositions between words and/or text segments and associates the resulting clusters with specific parts of the corpus, in this case, specific newspapers and magazines. The Alceste program provided confirmation of this analysis using a descending hierarchical classification whereby the corpus is first split into two parts, and then each part is further split into parts in an iterative way until a number of irreducible "classes" are produced.

\section{Analysis and results}

A first test using lexical distance in Hyperbase shows a clear split between the general press (Le Monde, Le Figaro, etc.) in the lower part of the tree in figure 1 and the economic press in the upper part, with the regional press squarely associated with the latter.

Surprisingly, newspapers that are at opposite ends on the ideological spectrum are very close in this corpus, that is, as a close reading of the pertinent articles from these newspapers confirms, they basically share the same worldview concerning language matters and their opposition to English. A closer look at the corpus allows to explain these results: (1) It appears that traditionally "progressive" newspapers and magazines (Le Monde, Le Monde Diplomatique, Marianne) are often very conservative when dealing with cultural and language issues; (2) English is often associated with Americanization which commentators from both the left and the right strongly resent, and (3) the circle of commentators who have "the authority" (in Bourdieu's sense; 1991: 109) to express their opinion is very small; as a result, the names of "authorized" scholars such as Claude Hagège and the late Claude Duneton appear in all national newspapers. All things considered, this first analysis demonstrates that the concerns of this very small elite is not shared by the rest of the population. Indeed these articles are completely absent in the regional press. Figure 1 below shows how articles from general newspapers such as Le Monde, Le Figaro and Libération, are 
closely related in terms of vocabulary and lexical fields (bottom left), but very distant from the economic press (top-center) and the regional press (top-right). ${ }^{1}$

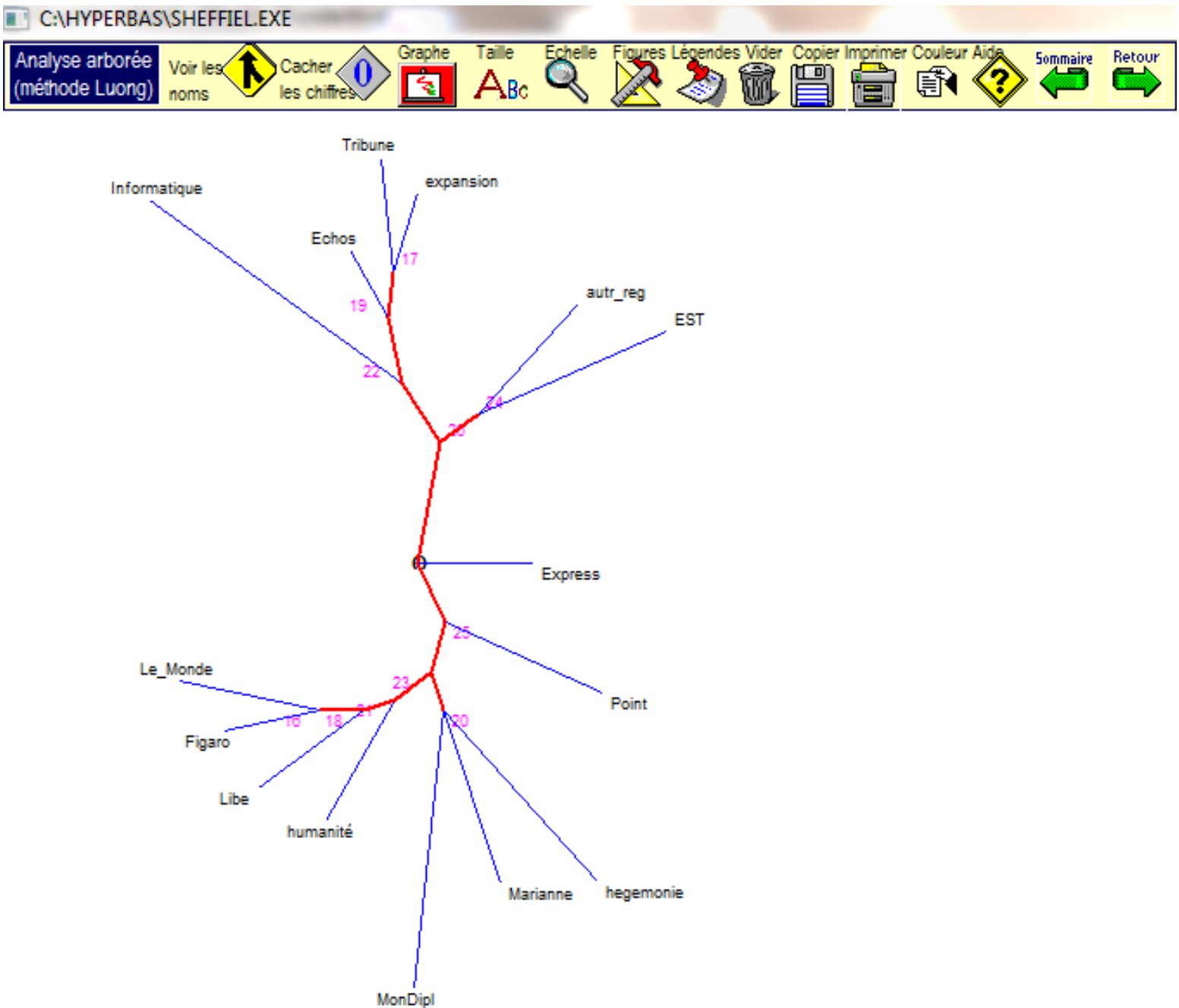

Figure 1: Lexical distance between different newspapers and magazines (Hyperbase).

The results of the second analysis using Alceste confirm the results of the first analysis and help us further refine them. The analysis resulted in 5 classes (figure 2): classes 2 and 3 cluster around the economic press with slightly different focuses, one on economic strategies, that is, the role of English in business communication, management, and corporate social responsibility, and the other on human relations such as employability, job hunting, etc. The regional press (class 4 ) is closely associated with these concerns, especially in the areas of

\footnotetext{
${ }^{1}$ For Bourdieu (1979: 518) the elitist character of the general press is not surprising. Indeed, "the reading of national newspapers, especially the most legitimate ones, is closely related to the educational level as a result of statutory attribution. A recognized school certificate strongly contributes to the feeling of rightfully belonging to the legitimate political and cultural universe, including feeling of being entitled to read a legitimate newspaper.
} 
employment, schooling and training. The general newspapers address two main themes: cultural politics (class 1), including language matters such as the defense of the French language, reactions against English, and traditional anti-Americanism, and (class 5) the worlds of music and literature. The world of music is often blamed for its "uncritical" adoption of English. English literature (or, as the French like to say, "la langue de Shakespeare") is used to contrast the noble and pure language of the great authors with the language of globalization, "Globish" and "sabir" (pidgin) that is making inroads into the French communication sphere.

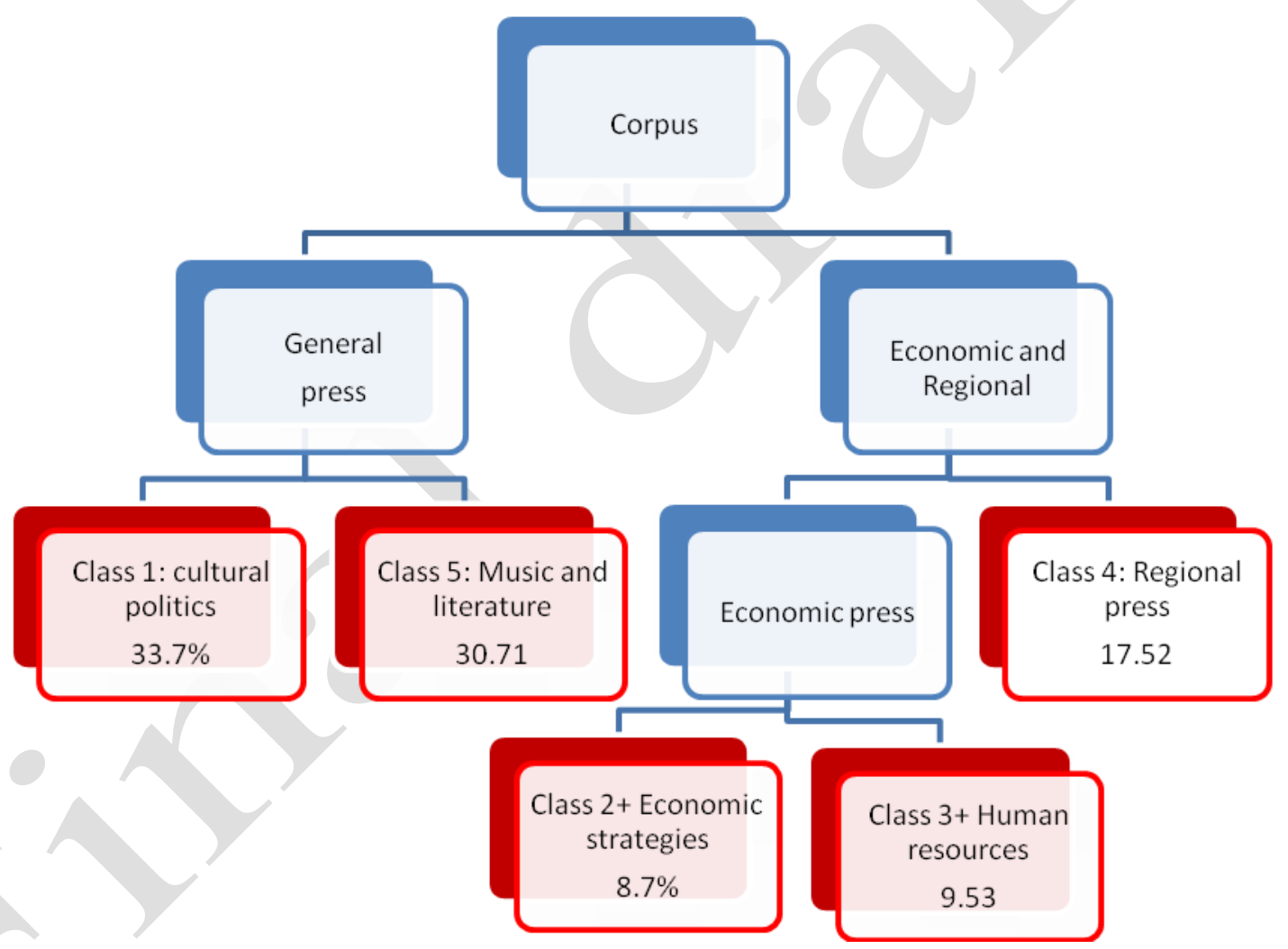

Figure 2: Descending hierarchical analysis (Alceste)

Here are some of the words that are most specific of each of the classes:

Class 1: africain, fédéral, fondamental, hégémonie, domination, danger, combat, fonctionnaire, identité, peuple, république, résistance, gouvernement (african, federal, fundamental, hegemony, domination, danger, fight, civil servant, identity, people, republic, resistance, government) 
Class 2 : capital, commercial, financier, Asie, Chine, international, entreprise, dirigeant, dollar, marché (capital, commercial, financial, Asia, China, international, enterprise, leader, dollar, market).

Class 3 : humain, évolutif, emploi, cadre, candidat, embaucher, évaluer, collaboration, compétent. ( human, progressive, employment, manager, candidate, hire, evaluate, collaboration, competent)

Class 4 : primaire, secondaire, obligatoire, enseignement, établissement, études, réussite, section, séjour, enseigner, bénéficier. (primary, secondary (education) compulsory, teaching, school, studies, success, section, stay-abroad, benefit)

Class 5 : Chanteur, auteur, album, écrivain, film, lecteur, romancier, musical, concert (singer, author, album, writer, film, reader, novelist, musical, concert.)

The two-dimensional projection of the results offered by Hyperbase (figure 3) shows that the different classes overlap considerably. There is almost complete overlap between classes 2 and 3 on the left, and 1 and 5 on the right, while class 4 overlaps with both groups, but considerably more with the first group. Thus the graph shows a strong opposition (30\% of the variance) between the left and the right half on the horizontal axis, that is, between the general press and the economic and regional press, and a weaker opposition between the top and the bottom half, that is, between the regional press and the national press, be it general newspapers (bottom right) or economic newspapers and magazines (bottom left) (18\% of the variance). The important overlap between economic and regional press is also confirmed with a smaller area of overlap between regional and general press, mainly in the domains of education and culture. 


\section{Factor analysis: terms + publications}

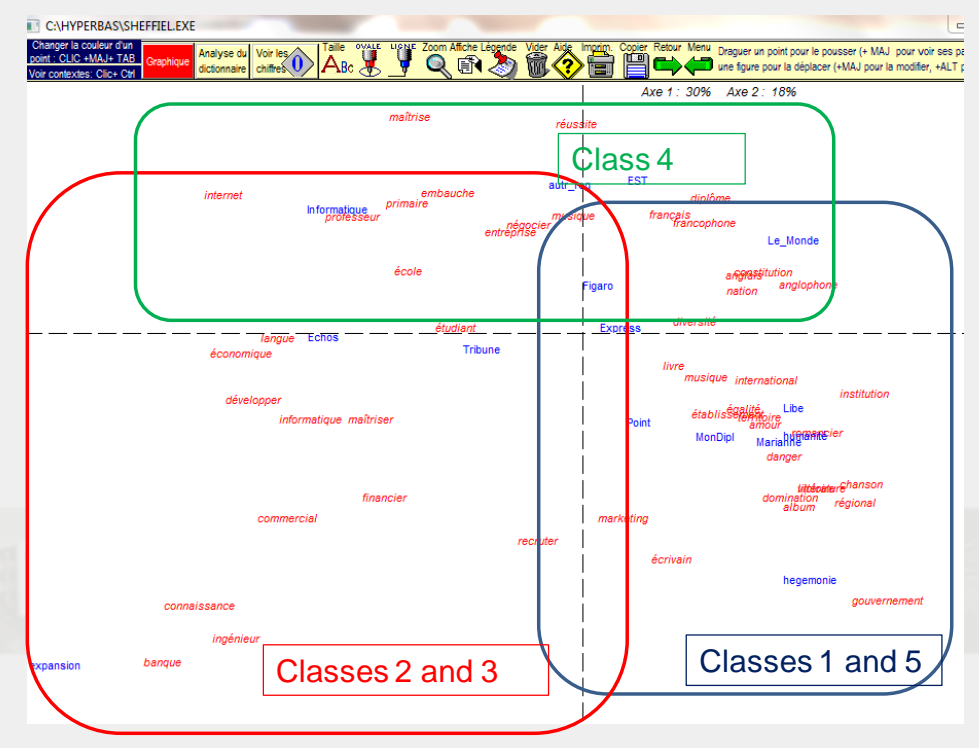

Figure 3: Factor analysis of terms and publications. See terms above

The opposition between terms on the horizontal axis also reflects an opposition between negative attitudes towards English on the right, i.e., in the general newspapers, and more neutral ones on the left, i.e., in the economic press and in magazines. . Indeed articles in the general press clearly adopt an ideological position (see examples below). Taken together, they display all aspects of what Van Dijk (1998: 268) has called an "ideological square" in that they

"Emphasize positive things about us.

Emphasize negative things about them.

De-emphasize negative things about us

De-emphasize positive things about them"

I used the term "neutral" for the economic and regional press because attitudes cannot be labeled positive, that is, there is no clear support for the use of English. Rather, they present their viewpoint as realistic, that is, as the result of a socio-linguistic context that is being imposed on us all. The media adopt a more laissez-faire attitude in which French people are encouraged strategically to adapt to a world in which English has become a necessary tool for success and economic survival. Whether this attitude is less ideological is 
of course a matter of definition ${ }^{2}$, but, in any case, the term "acceptance" would be more appropriate than enthusiastic support.

As a next step in the analysis, Wordsmith was used to detect the most common collocations and colligations in the corpus. Colligations, or grammatical constructions in general (l'anglais est devenu, qu'on le veuille ou non), are more rare but tend to be more productive in terms of ideological positioning than collocations (langue de Shakespeare, langue de communication) which tend to be more descriptive.

Concordances using these constructions were produced with the Hyperbase program. Below is a list of the main findings ${ }^{3}$ :

\section{A. Functions of English in today's world (l'anglais est devenu ...; English has become)}

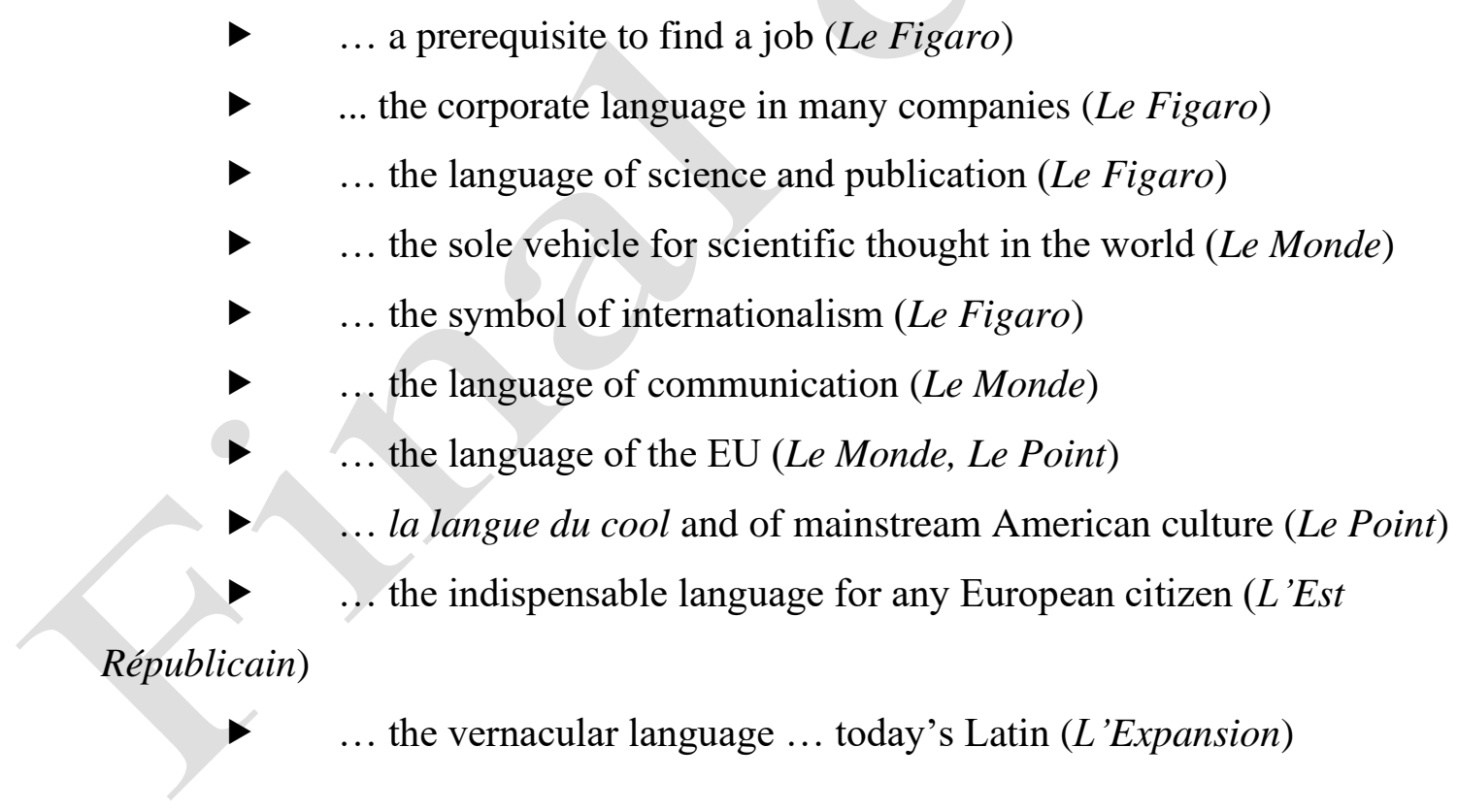

In short, newspapers unsurprisingly present English as a language of wider communication that, as such, is used for practical purposes, but it also has become a language of prestige, especially among the young and the professionally mobile.

\footnotetext{
${ }^{2}$ Indeed, Marxist theorists would probably call it "false consciousness"; see e.g., Eagleton (1991:89).

${ }^{3}$ Note that these are my own translations, which are deliberately as close to the French as possible, with an unavoidable loss of idiomaticity.
} 


\section{B. The "inner" qualities of English}

In business newspapers and magazines, English indexes images of dynamism, internationalism and modernity. Here again, even though English is often presented as "just a tool," symbolic values are at least as important as instrumental values. As a result, English often becomes a "company language," not for its practical value but for the image of the company:

- English is the language of business. Using it makes us sound more credible, more aggressive, especially in marketing. (Les Echos)

- Chris Viehbacher (CEO Sanofi-Avensis) speaks the language of the financial community and attempts to erase the franco-French (fr: franco-français) image of the company. (L'Express)

- Entre-temps, bien sûr, l'anglais s'impose peu à peu. C'est vrai dans les domaines déjà fortement américanisés que sont les sciences hard, la médecine soft, l'écologie green, l'alimentation light, mais aussi l'entertainment avec ses pitches, l'information avec ses lives, le business avec ces CEO, sans parler de tout le domaine d'Internet où la langue anglaise est constamment réinventée par les geeks et autres nerds (sic, no translation ; Le Point).

However, a number of articles mention the stress that is generated when a company "turns to English." Trade unions are particularly active in organizing meetings and conferences where they explain that a large number of managers lose their jobs after takeovers by international companies. One case often mentioned is that of a France Telecom engineer who committed suicide after being immersed against his will in an international context where his low proficiency in English made him unable to do his job. Another example is that of a PSA (Peugeot-Citroën) manager who said that the use of French in corporate meetings had been accepted in the past, but that it would no longer be tolerated after General Motors had purchased 7\% of the company's shares (both cases heard by this author when attending these meetings). Here are some statements from our corpus that illustrate these anxieties:

\footnotetext{
Foreign languages (i.e. English) generate "stress and insecurity," "mental fatigue," "possible discrimination in career evolution and in recruiting," and "costs in training." (Marianne)
} 
- An intranet site in English (Areva) "generates additional stress because it takes more time to read and understand". (Le Monde)

- Stress can be assimilated to a new form of slavery. (L'Expansion)

- The stress generated by this measure [adoption of English] initially had negative consequences on the productivity of a number of employees. (Le Monde)

\section{English as a necessary evil ("Qu'on le veuille ou non ...")}

The common expression "Qu'on le veuille ou non ..." (17 occurrences) refers to a kind of forced acceptance, often a sense of inevitability. This feeling is dominant in the economic press and in magazines, it is less present in the general press that still has faith in the fight against English.

- It's the clay pot against the iron pot. We are expected to be European, and therefore to speak English as it is the sole idiom of the new Europe. (Le Figaro)

- Whether we want it or not, soft power now speaks English [about music] (Le Point)

- Whether we want it or not, whether it pleases us or not, English is now the common language (langue véhiculaire) of the business world. (Les Echos)

- English has become, ... the Esperanto of the planet. (Le Monde)

\section{English as an international language is considered as a "non-}

\section{language"}

It is "not the language of Shakespeare" (106 occurrences) but rather "Globish," a term coined by former IBM executive Paul Nerrière in his popular book entitled "Parlez Globish. Don't speak English." (2011).

- The harm does not come from English, but from the American-like « sabir »... This kind of soft rubber American-like thing that contaminates the language. What exasperates me is that the French crawl to that American sabir. (Le Figaro) 
- The «sabir » has always exerted a beguiling charm among the colonized because it pulls the wool over their eyes. Ours is no exception. (Le Figaro)

- French administrations are forced to work using this « sabir » for

« European coordination », to bend to the Commission's obstinate americanophonia. (Le Figaro)

The term "sabir" (pidgin) is also frequently used (30 occurrences) to indicate that the English language used in daily communication is of lower quality. This term is particularly shocking when used by linguists and sociolinguistics such as Claude Hagège, whose "normal" agenda as a sociolinguist, one would expect, is to show that all languages are equally valid. In our corpus the word "sabir" not only refers to language but also to a reaction against American cultural imperialism. The use of English is perceived as a sign of submission; for Jean Dutourd, for example: "Everything started when the Americans won the war in our place."

\section{E. The invasion of English: Trojan horse or perfidious Albion}

American imperialism is presented as a Trojan horse, one that numbs the French before invading European space. The British, on the other hand, in their traditional role as a "perfidious Albion"4, are accused of taking advantage of their entry to the EU to anglicize Europe. The difference between the two countries is often blurred though, and presented as "Anglo-Saxon influence":

- The EU of six with four languages, of which French was a working language, became, after 20 years, in 1973, the EU of nine where English, the Trojan horse of American influence ... (Le Figaro)

- His success "Dance" ... makes us forget that since "Je t'aime moi non plus ..." the francophonie never managed to break into Albion (Libération)

- Concerning M. Serres: "Returning from 10 trips, here is what he sees: more English words on the walls of our cities or in the headlines of our newspapers than German during the occupation" (L'Humanité)

\footnotetext{
${ }^{4}$ For a history of the term, see http://www.historia.fr/web/expressions/la-perfide-albion-21-10-2010-44359
} 
- To spread words ... What Americans call "soft power." A power that is no longer based on arms, but on "meanings" which Americans noticed were more effective than physical confrontation. (Le Point)

\section{F. Images of French}

Adopting a strategy of distinction (Bourdieu 1979, E. Hall and M. Hall 1990) and in line with Van Dijk's ideological square mentioned above, authors and commentators present the French language as the positive mirror-image of English. As opposed to the language of business and science, it is the language of conversation (i.e., of culture and not communication, of alterity and not of egoism) that is endowed with human character and democratic values. Following the old clichés shaped during the $17^{\text {th }}$ and $18^{\text {th }}$ centuries, French continues to be presented as inherently rational and English as inherently pragmatic:

- Its traditional calling, ever more precious in the global market of a language of conversation, civil and hospitable among the non-businessed and the nonspecialists. (Le Figaro)

- The opposition is between one language, English, that privileges concrete and detailed observation, and another, French, which generalizes on the basis of particular cases and privileges logical articulations (Hagège). (Les Echos)

Finally, unlike English which has turned into Globish and/or a number of pidgins, French has kept its purity, even though, in spite of a heroic resistance, it is now being contaminated by English:

- The French language is not an object, it is a passion. It is a besieged fortress, a beauty that is being butchered, a purity that is being polluted. (Le Monde)

\section{Conclusion}

In recent years, the French have come to advocate multilingual policies within Europe as a new strategy in the defense of the French language. Many would now agree with the Martiniquais author Patrick Chamoiseau when he states in one of the articles in the present 
corpus that "French will remain powerful and magnificent where all languages are powerful and magnificent," that is, where all languages receive equal respect and recognition. This study shows through the press that a majority of the French, those who read the regional press and magazines, share Chamoiseau's opinion and do not see language contact between English and French as language conflict. However, the opinions expressed in the general press remain unchanged; if anything, they have grown more radical in recent years under the influence of a diminishing number of dominant voices. There are other voices in the French-speaking world, mainly outside Metropolitan France, that call for linguistic diversity, dialogue, and mutual enrichment. Besides Chamoiseau, we can mention Tahar Ben Jelloun, Amin Maalouf, Assia Djebar, and others, but these voices remain suspiciously absent from the major French newspapers. This study has shown that the press that is traditionally read by foreign scholars, journalists and commentators reflects the opinions of a very small and very conservative French cultural elite, not that of the majority of the French people. Indeed, most if not all the negative comments we cited here are from general elite newspapers, none from the regional press. This may provide an explanation for the strangely ${ }^{5}$ biased views that are often heard and read concerning French views towards English.

\section{References}

Bell, Allan. 1991. The Language of News Media. Oxford: Blackwell.

Bell, Allan. 1998. The discourse structure of news stories. In Allan Bell and Peter Garrett (eds.), Approaches to Media Discourse. Oxford: Blackwell.

Blommaert, Jan. 2005. Discourse: A Critical Introduction. Cambridge: Cambridge University Press. Histoire et Mesure, 18(3/4). 384-402.

Bonin, Emmanuel and Alain Dallo. 2003. Hyperbase et Lexico 3, outils lexicométriques pour l'historien.

Bourdieu, Pierre. 1979. La distinction. Paris: Minuit.

Bourdieu, Pierre. 1991. Language and Symbolic Power. Cambridge, MA: Harvard University Press.

Crystal, David. 2005. Towards a philosophy of language diversity. Paper prepared for

"Dialogue of Cultures," in honour of Viglis Finbogodottir. Reykjavik,14/15 April 2005.

\footnotetext{
${ }^{5}$ Most people living in France are indeed puzzled by these views.
} 
Deneire, Marc. 2008. English in the French workplace: Realism and anxieties. World Englishes 27(2). 181-195.

Dumartin, Sylvie and Céline Maillard. 2000. Le lectorat de la presse d'information générale. Insee Première online. Accessed 08/06/2014 <http://www.insee.fr/fr/ffc/ docs_ffc/ip753.pdf>

Duval, Julien. 2014. La presse - La presse et ses lecteurs. Encyclopaedia Universalis on-line. Accessed 08/06/2014 <http://www.universalis-edu.com/encyclopedie/presse-la-presse-etses-lecteurs/>

Eagleton, Terry. 1991. Ideology: An Introduction. London: Verso.

Estival, Dominique, and Alastair Pennycook. 2011. L'Académie française and Anglophone language ideologies. Language Policy 10. 325-341.

Etiemble, René. 1991. Parlez-vous franglais. Paris : Folio.

Eurydice. 2008. Chiffres clés de l'enseignement des langues en Europe. http://eacea.ec.europa.eu/education\%20/Eurydice/documents/key_data_series/095FR.pdf. Accessed 10/02/2010.

Fairclough, Norman. 1995. Critical Discourse Analysis: The Critical Study of Language. New York: Longman.

Flaitz, Jeffra. 1988. The Ideology of English: French Perceptions of English as a World Language. Berlin: Mouton-De Gruyter.

Hagège, Claude. 2008. Combat pour le français : Au nom de la diversité des langues et des cultures. Paris : Odile Jacob.

Hyperbase : Traitement documentaire et statistique des corpus textuels. 1977. Réalisé par Etienne Brunet. See <http://www.unice.fr/bcl/hyperbase?redirected_from=lolita.unice.fr/>

Hall, Edward, and Mildred Hall. 1990. Understanding Cultural Differences: Keys to Success in West Germany, France and the United States. Yarmouth: Intercultural Press

Kibbee, Douglas. 1993. Symposium on linguistic imperialism. Perspective 2. World Englishes (12(3). 342-347.

Martin, Elisabeth. 1998. Michael D. Picone: Anglicisms, neologisms, and Dynamic French. World Englishes 17(1). 97-98.

Martin, Elisabeth. 2007. Frenglish for sale: Multilingual discourses for addressing today's global consumer. World Englishes 26(2). 170-188.

Motte, Cedric. 2012. Nouvelle version du Monde.fr. News Resources. Accessed 08/06/2014 <http://www.newsresources.org/nouvelle-version-du-monde-fr-la-presentation-a-j-6> 
Nerrière, Jean-Paul. 2011. Parlez Globish. Don't speak English. Paris: Eyrolles

Power, Carla. 2007 “Not the Queen's English”. Newsweek International online. 7/3/2007. <www.msnbc.msn.com/id/7038031/site/newsweek/> (Accessed 3/10/2010)

PQR66 One. 2011. L'étude de référence de la presse en France. Audipresse. Accessed 14/01/2014 <http://fr.slideshare.net/atelierpqr/one-resultats-2011officialopt-12114644>

Robitaille, Louis-Bernard. Le salon des immortels: Une académie très française. Paris : Editions Denoël.

Serres, Michel. 2013. Je lance un appel pour faire la grève de l'anglais. La Dépêche.fr. 20 Oct. 2013. Accessed 08/06/2014 <http://www.ladepeche.fr/article/2013/10/20/1735337michel-serres-lance-appel-faire-greve-anglais.html>

Van Dijk, Teun. 1998. Ideology : A Multi-disciplinary Approach. Thousand Oaks, CA: Sage.

Wordsmith Tools, Version 4. Written by Mike Scott. See < http://www.lexically.net/ LexicalAnalysisSoftware/index.html> 